\title{
3p14 Loss of Heterozygosity
}

National Cancer Institute

\section{Source}

National Cancer Institute. 3p14 Loss of Heterozygosity. NCI Thesaurus. Code C146641.

A molecular abnormality that results in monoallelic loss of function mutations located within $3 p 14$. 